\title{
Nanocrystalline Mixed Oxides Containing Magnesium Prepared by a Combined Sol-Gel and Self-Combustion Method for Catalyst Applications
}

\author{
Nicolae Rezlescu ${ }^{1}$, Elena Rezlescu ${ }^{1}$, Liliana Sachelarie ${ }^{2}$, Paul Dorin Popa ${ }^{1}$, Corneliu Doroftei ${ }^{1}$, \\ Maria Ignat ${ }^{3}$ \\ ${ }^{1}$ National Institute of Research and Development for Technical Physics, Iasi, Romania; ${ }^{2}$ Apolonia University, Iasi, Romania; ${ }^{3}$ Al. I. \\ Cuza University, Iasi, Romania. \\ Email: nicolae.rezlescu@gmail.com
}

Received June $13^{\text {th }}, 2013$; revised July $12^{\text {th }}, 2013$; accepted July $20^{\text {th }}, 2013$

Copyright (C) 2013 Nicolae Rezlescu et al. This is an open access article distributed under the Creative Commons Attribution License, which permits unrestricted use, distribution, and reproduction in any medium, provided the original work is properly cited.

\begin{abstract}
$\mathrm{MgFe}_{2} \mathrm{O}_{4}$ spinel ferrite and $\mathrm{La}_{0.6} \mathrm{~Pb}_{0.2} \mathrm{Mg}_{0.2} \mathrm{MnO}_{3}$ perovskite nanopowders were synthesized by a combined sol-gel and self-combustion method and heat treatment. The morphological and structural characterization of the obtained powders has been performed with various techniques: X-ray diffraction (XRD), SEM observations, EDAX spectroscopy and BET analysis. The samples have been catalytically tested in flameless combustion reaction of acetone, benzene, propane and $\mathrm{Pb}$ free gasoline at atmospheric pressure. The results revealed a higher catalytic activity of $\mathrm{La}_{0.6} \mathrm{~Pb}_{0.2} \mathrm{Mg}_{0.2}$ $\mathrm{MnO}_{3}$ perovskite than that of $\mathrm{MgFe}_{2} \mathrm{O}_{4}$ ferrite. This higher catalytic activity can be ascribed to smaller crystallite size $(27 \mathrm{~nm})$, larger surface area $\left(8.5 \mathrm{~m}^{2} / \mathrm{g}\right)$ and the presence of manganese cations with variable valence $\left(\mathrm{Mn}^{3+}-\mathrm{Mn}^{4+}\right) . \mathrm{The}^{2}$ current results suggest that $\mathrm{La}_{0.6} \mathrm{~Pb}_{0.2} \mathrm{Mg}_{0.2} \mathrm{MnO}_{3}$ perovskite is preferable to the $\mathrm{Mg}$ ferrite and that it can be a promising catalyst for acetone and propane combustion at low temperatures.
\end{abstract}

Keywords: Oxides; Sol-Gel-Self-Combustion; Microstructure; SEM; XRD; Catalytic Properties

\section{Introduction}

The aim of the present work is to comparatively estimate the physical and catalytic properties of two magnesium containing oxide compounds prepared by sol-gel-selfcombustion: $\mathrm{MgFe}_{2} \mathrm{O}_{4}$ spinel ferrite and $\mathrm{La}_{0.6} \mathrm{~Pb}_{0.2} \mathrm{Mg}_{0.2}$ $\mathrm{MnO}_{3}$ perovskite. The role of the $\mathrm{Mg}$ ion in a ceramic is to prevent the growth of the grains by reducing the grain boundary mobility.

In the last years, the use of perovskite or spinel type oxide compounds as catalyst has been widely investigated in order to find a catalyst with high thermal stability [1] and low temperature activity [2]. Transition metal perovskites as $\mathrm{LaMnO}_{3}$ are known to be very good oxidation catalyst. The partial substitution of $\mathrm{La}^{3+}$ ions by lower valence ions ( such as $\mathrm{Pb}^{2+}, \mathrm{Mg}^{2+}, \mathrm{Ca}^{2+}$ ) produces the partial oxidation of $\mathrm{Mn}^{3+}$ to $\mathrm{Mn}^{4+}$ ions and the increase in oxygen vacancies which enhance the catalytic activity of the perovskite. The stability of $\mathrm{Mn}^{4+}$ ions seems to be the most important factor in the catalytic activity of perovskite manganites [3]. Saracco et al. [4] reported the positive effect of the $\mathrm{Mg}$ substitution in the basic $\mathrm{LaMnO}_{3}$ perovskite on the catalytic activity of the resulting perovskite.

Oliva et al. [5] found that the preparation procedure can have a remarkable effect on the physico-chemical characteristics and the catalytic properties of perovskites. In the present work we applied a nonconventional procedure which is a combined sol-gel and self-combustion method [6] followed by thermal treatment. In this procedure the heat generated by an exothermic combustion reaction was used for synthesis reaction of the oxide ceramics. The intimate mixing of constituent ions so that nucleation and crystallization can occur at relatively low temperature is the main feature of this method. Sol-gelself-combustion method offers a number of advantages including homogeneous mixing (on the atomic scale), low energy cost, easy manufacturing and the control of the grain size by subsequent heat treatments.

The phase composition, microstructural features, compositional homogeneity, specific surface area and pore size of the obtained powders were studied by X-ray powder diffraction analysis (XRD), scanning electron 
microscopy (SEM) coupled with energy dispersive X-ray analysis (EDAX) and nitrogen adsorption/desorption at $\sim 77$ $\mathrm{K}$. The obtained nanopowders $\left(\mathrm{La}_{0.6} \mathrm{~Pb}_{0.2} \mathrm{Mg}_{0.2} \mathrm{MnO}_{3}\right.$ and $\mathrm{MgFe}_{2} \mathrm{O}_{4}$ ) have been tested as catalysts for the catalytic flameless combustion of acetone, benzene, propane and $\mathrm{Pb}$ free gasoline. The effect of the phase composition and structure on the performance of the two catalyst samples has been investigated.

\section{Experimental}

\subsection{Sample Preparation}

$\mathrm{MgFe}_{2} \mathrm{O}_{4}$ spinel ferrite and $\mathrm{La}_{0.6} \mathrm{~Pb}_{0.2} \mathrm{Mg}_{0.2} \mathrm{MnO}_{3}$ perovskite have been prepared by sol-gel-self-combustion method [6], using metal nitrates, ammonium hydroxide and polyvinyl alcohol as starting materials. This method included the following steps: 1) dissolution of metal nitrates in deionized water; 2) polyvinyl alcohol $(10 \%$ concentration) addition to nitrate solution to make a colloidal solution; 3$) \mathrm{NH}_{4} \mathrm{OH}(10 \%$ concentration) addition to increase $\mathrm{pH}$ to about 8 ; 4) stirring at $80^{\circ} \mathrm{C}$ to turn the sol of metal hydroxides into gel; 5) drying the gel at $100^{\circ} \mathrm{C}$; 6) self-combustion of the dried gel; 7) calcinations at $500^{\circ} \mathrm{C}$ for $30 \mathrm{~min}$ of the burnt powder to eliminate any residual ceramic compound; 8 ) heat treatment of the powders. $\mathrm{MgFe}_{2} \mathrm{O}_{4}$ powder was treated at $900^{\circ} \mathrm{C}$ for 10 min and $\mathrm{La}_{0.6} \mathrm{~Pb}_{0.2} \mathrm{Mg}_{0.2} \mathrm{MnO}_{3}$ was treated at $1000^{\circ} \mathrm{C}$ for $320 \mathrm{~min}$. The higher temperature for longer time interval for perovskite was preferred for two major reasons. First, the heat released by the combustion reaction is not sufficient to raise the system temperature to a level that allows the growth of the perovskite crystallites. Second, $\mathrm{La}_{0.6} \mathrm{~Pb}_{0.2} \mathrm{Mg}_{0.2} \mathrm{MnO}_{3}$ is an oxide compound and it is possible that the migration of ions required for the formation of the perovskite structure demands some residence time at high temperature. In Figure 1 is given the flow diagram for preparing process by sol-gel self-combustion and heat treatment. By this procedure oxide compounds can be prepared at much lower temperature than by the conventional solid state reaction method.

\subsection{Characterization Techniques}

Crystal structure and phase composition of the samples were analyzed by XRD. X-ray diffraction measurements of the powders were performed at room temperature using PANANALYTICAL $X$ ' PERT PRO MPD powder diffractometer and $\mathrm{CuK} \alpha$ radiation $(\lambda=1,542,512 \AA)$. The spectra were scanned between 20 and $80^{\circ}(2 \theta)$ at a rate of $2 \%$ min. The average crystallite size was evaluated based on XRD peak broadening using the Scherer equation $\mathrm{D}=0.9 \lambda / \beta \cos \theta$, were $\lambda$ is radiation wavelength $(0.15405 \mathrm{~nm})$ of $\mathrm{CuK} \alpha, \beta$ is the half width of the peak and $\theta$ is the Bragg diffraction peak angle. A scanning

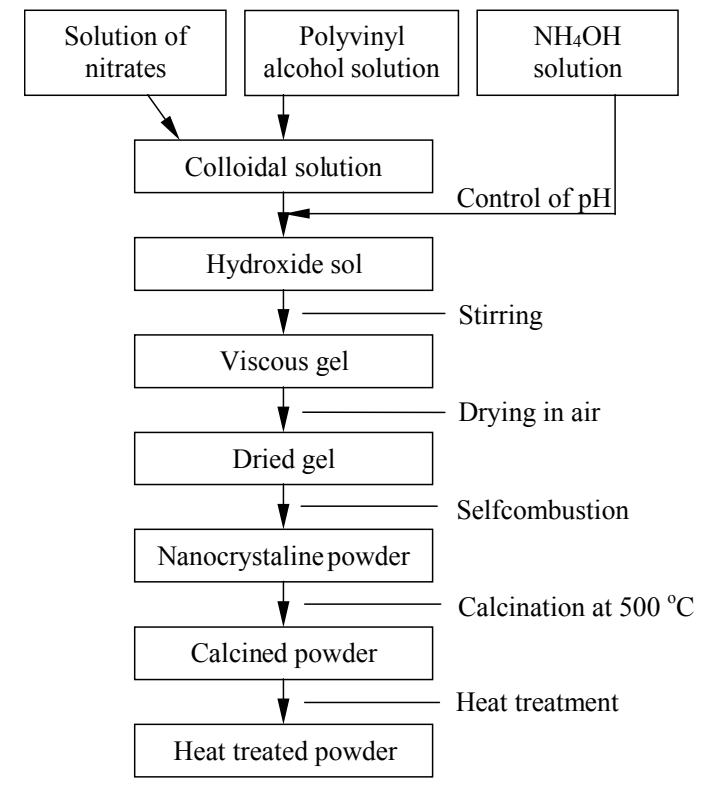

Figure 1. Flow diagram for preparing the oxide nanopowders by combined sol-gel and self-combustion route.

electron microscope (JEOL-200 CX) was used to observe the surface morphology. Textural characteristics were investigated by means of specific surface area determined by BET (Brunauer-Emmett-Teller) [7] method from the nitrogen sorption isotherms at $77 \mathrm{~K}$. Adsorption/desorption isotherms were determined with NOVA-2200 apparatus. The pore size distribution (PSD) curves were obtained from sorption isotherms using BJH (Barret-Joyner-Halenda) method [7]. The chemical composition of the surface particles was examined with Energy Dispersive X-ray Spectrometer (EDS).

\section{Results and Discussion}

The XRD patterns at room temperature of the heat treated samples are shown in Figure 2. Results revealed that all samples were monophase without any other second phase. Cubic spinel structure ( $\mathrm{Fd} 3 \mathrm{~m}$ space group) was identified for $\mathrm{MgFe}_{2} \mathrm{O}_{4}$ sample and cubic perovskite structure (Fm3m space group) for $\mathrm{La}_{0.6} \mathrm{~Pb}_{0.2} \mathrm{Mg}_{0.2} \mathrm{MnO}_{3}$. The broadening of the peaks implies the generation of crystallites in the nanosize range. The lattice parameters and average crystallite size derived from XRD data are given in Table 1. The values of the lattice parameters almost coincide with those presented in the literature in analogous compounds [8]. It is evident the nanosized crystallinity and that the crystallite size and density behave inversely to each other with respect to $\mathrm{Mg}$ concentration. Smaller crystal size $(27.28 \mathrm{~nm})$ and higher density $\left(8.33 \mathrm{~g} / \mathrm{cm}^{3}\right)$ were found in $\mathrm{La}_{0.6} \mathrm{~Pb}_{0.2} \mathrm{Mg}_{0.2} \mathrm{MnO}_{3}$ perovskite which contains $20 \%$ molar Mg only.

SEM micrographs showing surface morphology of the 


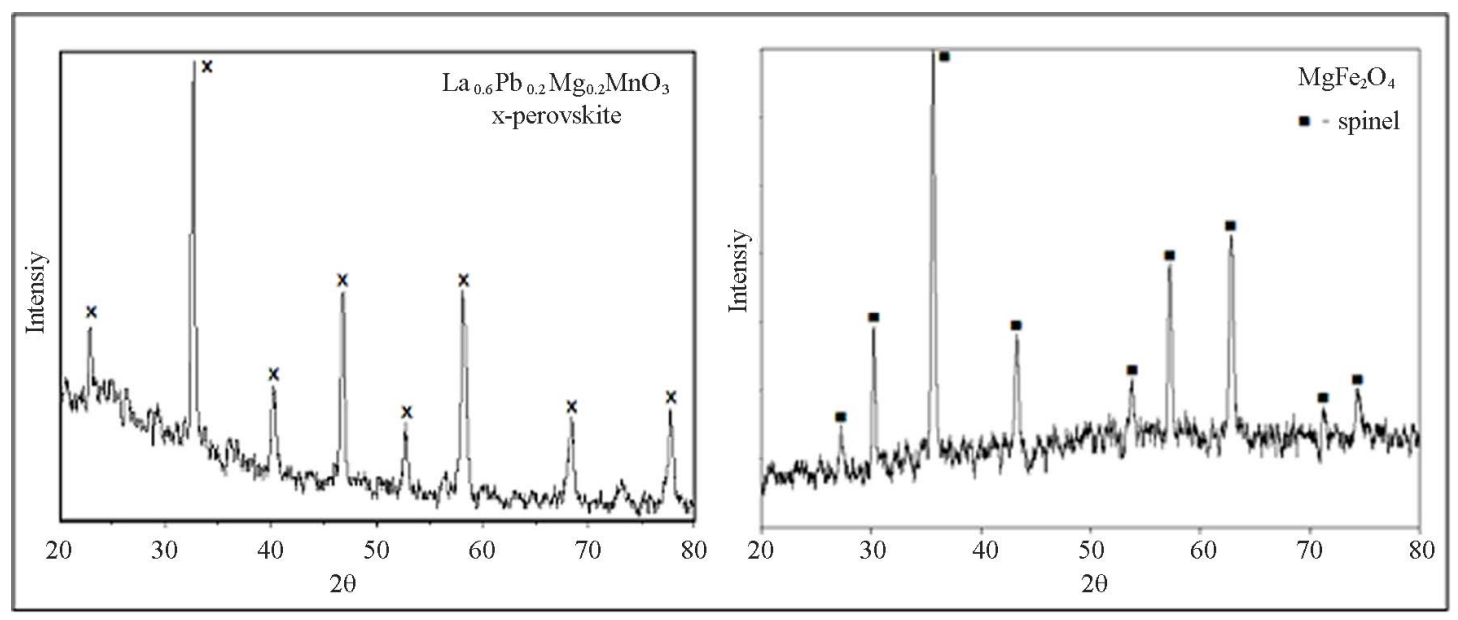

Figure 2. XRD patterns for $\mathrm{La}_{0.6} \mathrm{~Pb}_{0.2} \mathrm{Mg}_{0.2} \mathrm{MnO}_{3}$ and $\mathrm{MgFe}_{2} \mathrm{O}_{4}$ nanopowders.

Table 1. Structure characteristics.

\begin{tabular}{cccc}
\hline Sample composition & $\begin{array}{c}\text { Lattice parameter } \\
(\mathrm{nm})\end{array}$ & $\begin{array}{c}\text { Crystal } \\
\text { size } \\
(\mathrm{nm})\end{array}$ & $\begin{array}{c}\mathrm{dx} \\
\left(\mathrm{g} / \mathrm{cm}^{3}\right)\end{array}$ \\
\hline $\mathrm{MgFe}_{2} \mathrm{O}_{4}$ & 0.8366 & 41.78 & 4.55 \\
$\mathrm{La}_{0.6} \mathrm{~Pb}_{0.2} \mathrm{Mg}_{0.2} \mathrm{MnO}_{3}$ & 0.7740 & 27.28 & 8.33 \\
\hline
\end{tabular}

two powders are shown in Figure 3. One can note significant differences in the microstructure of the two samples. Small agglomerates of fine grains with irregular shape can be observed in the perovskite powder, whereas $\mathrm{MgFe}_{2} \mathrm{O}_{4}$ spinel powder is characterized by the presence of dense and larger agglomerates.

The EDAX patterns confirm the homogeneous mixing of atoms in both samples and the purity of the chemical compositions. Figure 4 shows EDAX spectrum for $\mathrm{MgFe}_{2} \mathrm{O}_{4}$ and Table 2 shows the elemental composition. $\mathrm{The} \mathrm{Mg} / \mathrm{Fe}$ ratio is found close to the theoretical value (0.5) and this is proof of homogeneous distribution of the elements in the solid.

Nitrogen adsorption/desorption isotherms at $\sim 77 \mathrm{~K}$ were used to obtain information about the specific surface area $\mathrm{S}_{\mathrm{BET}}$, the pore volume and the pore size in the ceramic particles. The isotherms for the both samples are presented in Figure 5. As can be seen, the desorption branch does not follow the adsorption branch, but forms a hysteresis loop of type $\mathrm{H} 3$ according to the International Union of Pure and Applied Chemistry (IUPAC) classification [9]. H3 type hysteresis is typically for materials with an interparticle mesoporosity (pore size 2 $50 \mathrm{~nm}$ ) [7]. However, a clear decision with regard to the type of hysteresis loop is not always possible. The factors which determine the shape of the hysteresis loop are still not fully known for disordered pore system [10].

Pore size distribution curves (PSD by BJH method) for both samples obtained from $\mathrm{N}_{2}(\sim 77 \mathrm{~K})$ sorption iso- therms are given inset of Figure 5. There are two distinct ranges for pore size distribution for $\mathrm{MgFe}_{2} \mathrm{O}_{4}$. These are between 2.7 and $3 \mathrm{~nm}$ and between 5.5 and $6.3 \mathrm{~nm}$. The pore size distribution of $\mathrm{La}_{0.6} \mathrm{~Pb}_{0.2} \mathrm{Mg}_{0.2} \mathrm{MnO}_{3}$ was found to be different from that of $\mathrm{MgFe}_{2} \mathrm{O}_{4}$. Four ranges with different pore sizes were evidenced: two narrow ranges, from 3 to $3.5 \mathrm{~nm}$ and from 4.8 to $5.2 \mathrm{~nm}$, and two wider pore ranges, from 6.8 to $8.5 \mathrm{~nm}$ and from 13 to $15 \mathrm{~nm}$. But all the pore sizes are within the mesoporous region.

The BET surface area, pore volume and average pore diameter are given in Table 3. BET specific surface area $\left(8.5 \mathrm{~m}^{2} / \mathrm{g}\right)$ of $\mathrm{La}_{0.6} \mathrm{~Pb}_{0.2} \mathrm{Mg}_{0.2} \mathrm{MnO}_{3}$ is higher than that of $\mathrm{MgFe}_{2} \mathrm{O}_{4}\left(4.0 \mathrm{~m}^{2} / \mathrm{g}\right)$. Larger pore volume and smaller particle size determine the increased $\mathrm{S}_{\mathrm{BET}}$ value of the perovskite. The characteristics of $\mathrm{MgFe}_{2} \mathrm{O}_{4}$ are comparable to those of other spinel ferrites reported in [11].

The catalytic testing of the two catalyst samples in the flameless combustion of four VOCs (acetone, propane, benzene and $\mathrm{Pb}$ free gasoline) was carried out at atmospheric pressure in a flow-type set-up previously described by us [12]. The catalyst powder $(0.3-0.5 \mathrm{~g})$ was sandwiched between two layers of quartz wool in a quartz tubular micro-reactor $(\Phi=7 \mathrm{~mm})$ placed in an electrical furnace. The increase of the temperature was made stepwise. At every predetermined temperature, as a result of catalytic combustion, the gas concentration at the exist of reactor will be smaller than the inlet gas concentration. The degree of conversion of gases over catalysts at a certain temperature was calculated as:

$$
\text { Conv }=\frac{c_{\text {in }}-c_{\text {out }}}{c_{\text {in }}} \times 100 \%,
$$

where $c_{\text {in }}$ and $c_{\text {out }}$ are the inlet and outlet gas concentration, respectively, measured by a photo-ionization detector (PID-TECH) for VOCs. Data were collected when the flameless catalytic combustion had reached a steady state, after about 20 minutes at each temperature. These ex- 


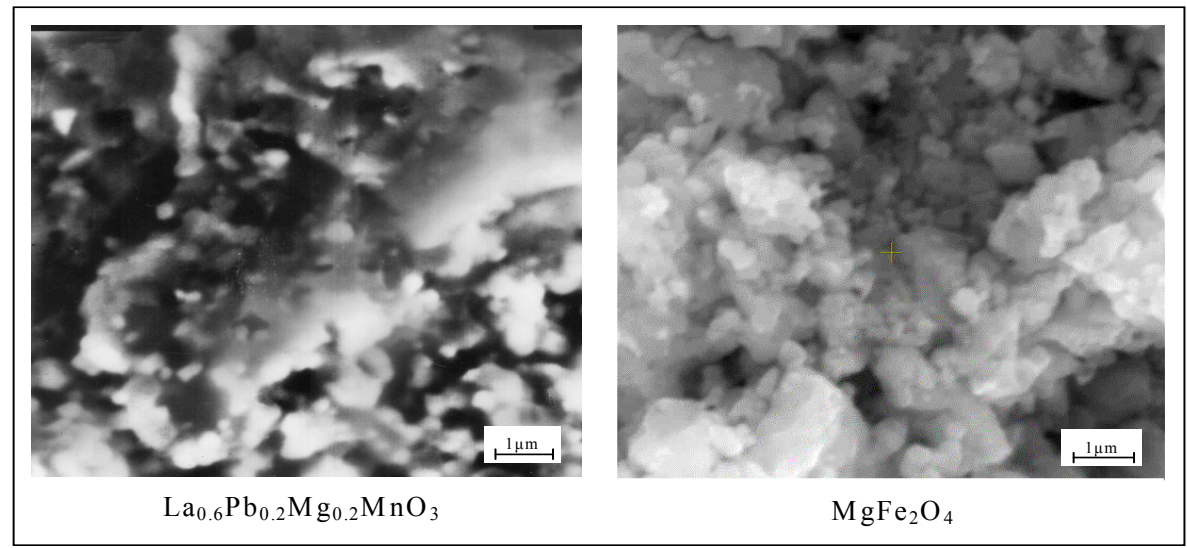

Figure 3. SEM micrographs for $\mathrm{La}_{0.6} \mathrm{~Pb}_{0.2} \mathrm{Mg}_{0.2} \mathrm{MnO}_{3}$ and $\mathrm{MgFe}_{2} \mathrm{O}_{4}$ nanopowders.

Table 2. EDAX analysis of $\mathrm{MgFe}_{2} \mathrm{O}_{4}$ powder.

\begin{tabular}{cc}
\hline $\mathrm{O}(\mathrm{at} \%)$ & 50.34 \\
$\mathrm{Mg}(\mathrm{at} \%)$ & 17.60 \\
$\mathrm{Fe}(\mathrm{at} \%)$ & 31.99 \\
$\mathrm{Mg} / \mathrm{Fe}$ & 0.55 \\
\hline
\end{tabular}

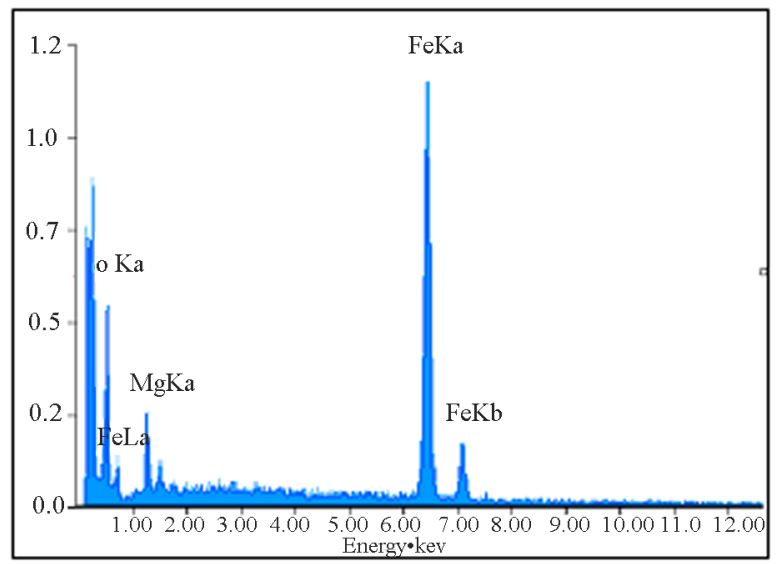

Figure 4. $\mathrm{EDAX}$ spectrum for $\mathrm{MgFe}_{2} \mathrm{O}_{4}$ ferrite heat treated at $900^{\circ} \mathrm{C}$ for $10 \mathrm{~min}$.

periments were repeated decreasing the temperature and similar results were obtained.

The catalytic reactions were investigated in the $20^{\circ} \mathrm{C}$ $550^{\circ} \mathrm{C}$ range. Figure 6 plots the gas conversion over the two catalysts as a function of reaction temperature. One can note the followings:

1) The catalytic activity of the two nanomaterials in the gas combustion is strongly influenced by the reaction temperature. Increasing the reaction temperature promotes gas conversion over the two catalysts.

2) The reactions involving spinel type oxide occur at higher temperatures than in the presence of the perovskite catalyst.

3) The activities of the two catalysts differ signifi-
Table 3. Surface characteristics of $\mathrm{MgFe}_{2} \mathrm{O}_{4}$ and $\mathrm{La}_{0.6} \mathrm{~Pb}_{0.2}$ $\mathrm{Mg}_{0.2} \mathrm{MnO}_{3}$ powders.

\begin{tabular}{ccc}
\hline Characteristics & $\mathrm{MgFe}_{2} \mathrm{O}_{4}$ & $\mathrm{La}_{0.6} \mathrm{~Pb}_{0.2} \mathrm{Mg}_{0.2} \mathrm{MnO}_{3}$ \\
\hline BET surface area $\left(\mathrm{m}^{2} / \mathrm{g}\right)$ & 4.0 & 8.5 \\
BJH pore volume $(\mathrm{cc} / \mathrm{g})$ & 0.006 & 0.021 \\
BJH average pore size $(\mathrm{nm})$ & 4.25 & 7.50 \\
Particle size $\mathrm{D}_{\text {BET }}{ }^{*}(\mathrm{~nm})$ & 33.7 & 89.2 \\
\hline
\end{tabular}

${ }^{*} D_{\text {BET }}$ was calculated using $\mathrm{S}_{\mathrm{BET}}[7]$.

cantly (Figure 6). From all experiments, $\mathrm{La}_{0.6} \mathrm{~Pb}_{0.2} \mathrm{Mg}_{0.2}$ $\mathrm{MnO}_{3}$ perovskite resulted to be more active than $\mathrm{Mg}$ $\mathrm{Fe}_{2} \mathrm{O}_{4}$ ferrite. The conversion degree of the gases over perovskite catalyst may even exceed $90 \%$ at $500^{\circ} \mathrm{C}$, whereas over spinel catalyst the conversion is below $80 \%$. The worst result was obtained for $\mathrm{Pb}$ free gasoline combustion over spinel catalyst: $34 \%$ conversion at $550^{\circ} \mathrm{C}$.

The temperature of the $50 \%$ conversion of a gas, $\mathrm{T}_{50}$, was used to estimate the catalytic activity of the two catalysts: $\mathrm{MgFe}_{2} \mathrm{O}_{4}$ spinel and $\mathrm{La}_{0.6} \mathrm{~Pb}_{0.2} \mathrm{Mg}_{0.2} \mathrm{MnO}_{3}$ perovskite. At $\mathrm{T}_{50}$ temperature the catalytic activity for the total oxidation of gases is sufficiently high. The lower $\mathrm{T}_{50}$ is, the higher the activity. The $\mathrm{T}_{50}$ values for each catalyst and each VOC (except for $\mathrm{Pb}$ free gasoline) are plotted in bar diagram presented in Figure 7. The $\mathrm{T}_{50}$ values for benzene and acetone conversion over $\mathrm{La}_{0.6}$ $\mathrm{Pb}_{0.2} \mathrm{Mg}_{0.2} \mathrm{MnO}_{3}$ are in agreement with those reported by Spinicci et al. [13]. For gasoline conversion over $\mathrm{MgFe}_{2} \mathrm{O}_{4}$ catalyst, $\mathrm{T}_{50}$ exceeds $550^{\circ} \mathrm{C}$.

The catalyst stability of the two materials was studied and no deactivation was observed in any of the samples after 24 hours.

The better catalyst performance of $\mathrm{La}_{0.6} \mathrm{~Pb}_{0.2} \mathrm{Mg}_{0.2}$ $\mathrm{MnO}_{3}$ perovskite in comparison with $\mathrm{MgFe}_{2} \mathrm{O}_{4}$ spinel can be attributed to smaller crystallite size $(27 \mathrm{~nm})$, larger surface area $\left(8.5 \mathrm{~m}^{2} / \mathrm{g}\right)$ and the presence of manga- 


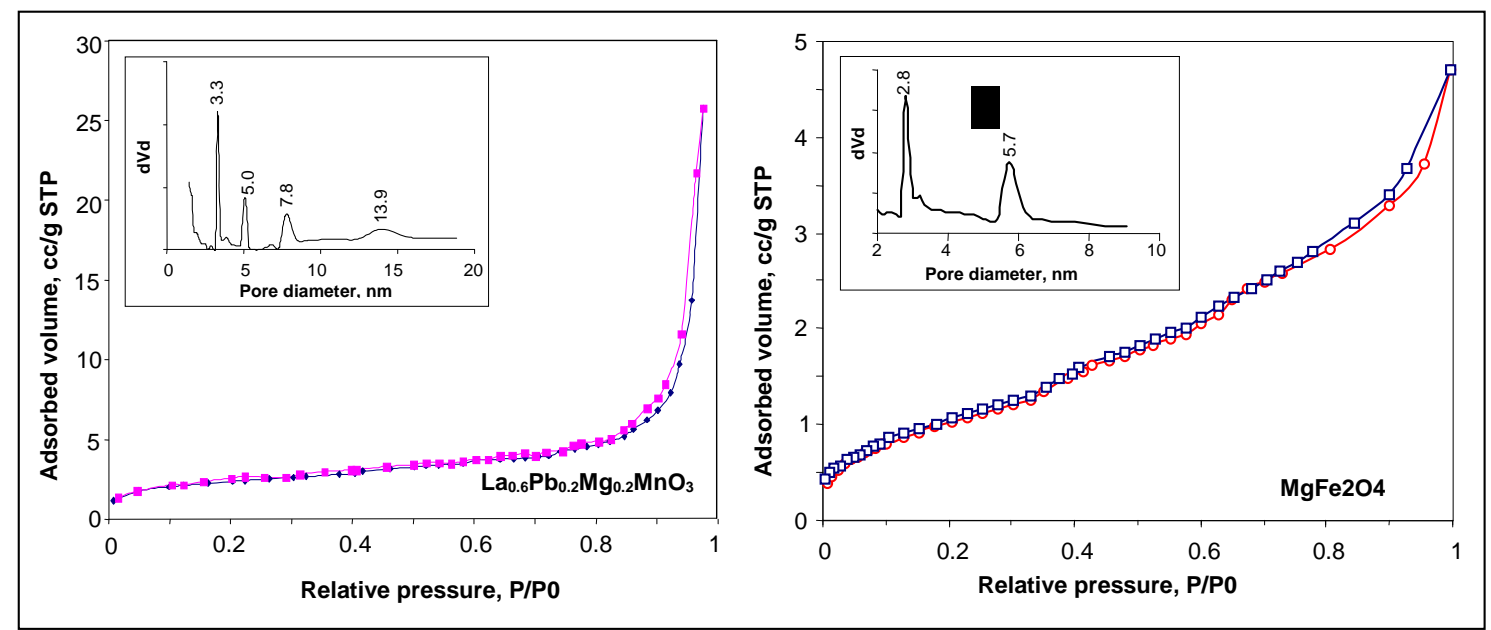

Figure 5. $\mathrm{N}_{2}$ adsorption/desorption isotherms at $77 \mathrm{~K}$ of the two powders: $\mathrm{La}_{0.6} \mathrm{~Pb}_{0.2} \mathrm{Mg}_{0.2} \mathrm{MnO}_{3}$ perovskite and $\mathrm{MgFe}_{2} \mathrm{O}_{4}$ spinel ferrite $(\bullet \circ$ : the adsorption branch and $\bullet \square$ : the desorption branch). Inset: the pore size distribution graphs.

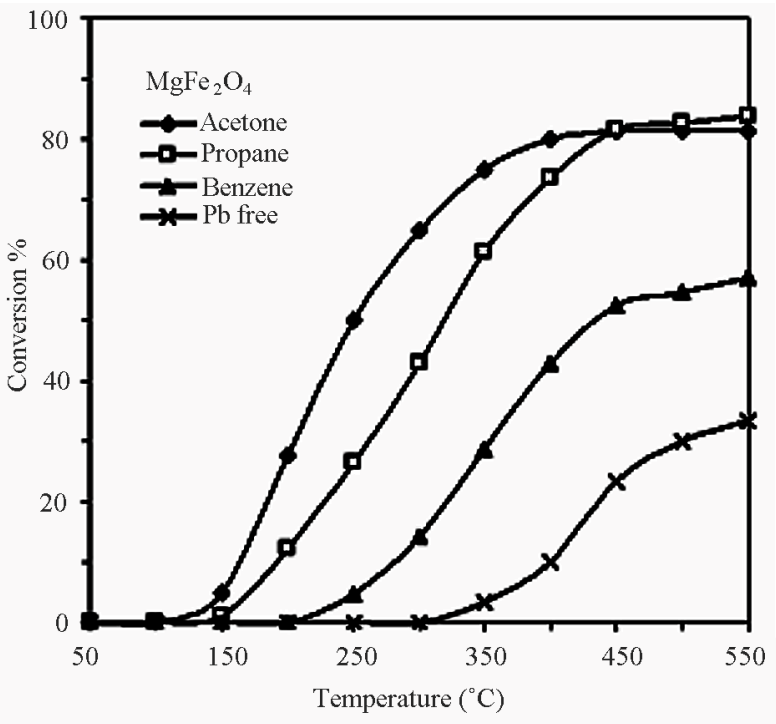

(a)

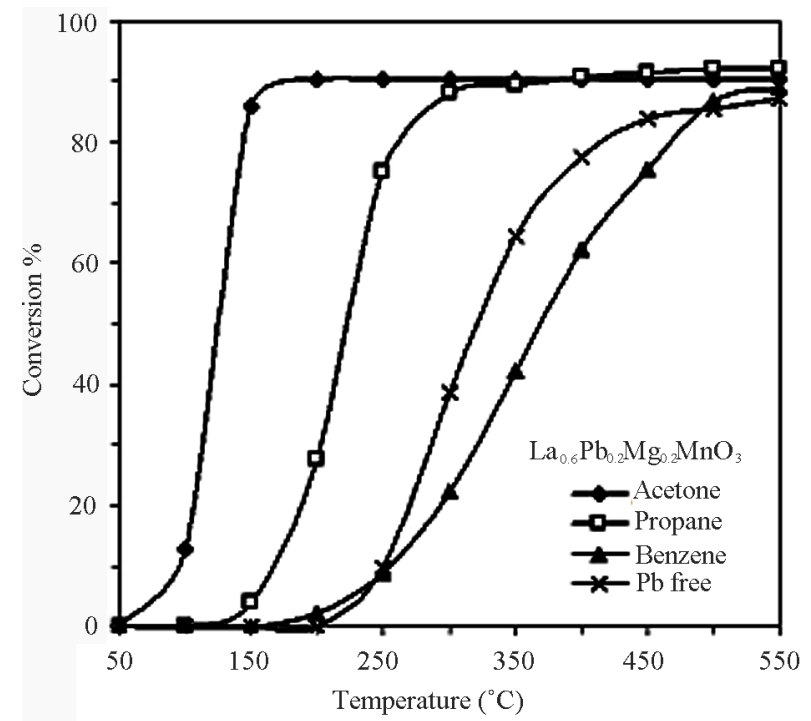

(b)

Figure 6. Conversion of acetone, propane, benzene and $\mathrm{Pb}$ free gasoline vs. temperature over $\mathrm{La}_{0.6} \mathrm{~Pb}_{0.2} \mathrm{Mg}_{0.2} \mathrm{MnO}_{3}$ perovskite and $\mathrm{MgFe}_{2} \mathrm{O}_{4}$ spinel catalysts.

nese cations with variable valence. Redox titration method showed that $\mathrm{La}_{0.6} \mathrm{~Pb}_{0.2} \mathrm{Mg}_{0.2} \mathrm{MnO}_{3}$ perovskite contains a considerable concentration of $\mathrm{Mn}^{4+}$ ions $(35 \%)$ in addition to $\mathrm{Mn}^{3+}$ ions, which form to compensate the charge change caused by $\mathrm{Mg}^{2+}$ and $\mathrm{Pb}^{2+}$ substitutions for $\mathrm{La}^{3+}$. The presence of $\mathrm{Mn}^{3+}-\mathrm{Mn}^{4+}$ ions implies oxygen vacancies which favor the increase in the oxygen ion species $\left(\mathrm{O}^{-}, \mathrm{O}_{2}^{-}, \mathrm{O}^{2-}\right)$ adsorbed on perovskite surface [14]. The larger the number of oxygen ions adsorbed, the faster the oxidation of gases would be. The gas oxidation activity over catalyst is related to the ability of surface adsorbed oxygen to activate gas and to the ability of gas phase oxygen to fill surface oxygen vacancies. We have not excluded the involvement of the lattice oxygen although its mobility is smaller than that of surface adsorbed oxygen. The formation of the defective structures in the perovskite structure by partial substitution of La by ions of lower valence facilitates the mobility of the lattice oxygen (via oxygen vacancy mechanism [15]) and the material will be more active for oxidation reactions [16].

\section{Conclusion}

In this work the combined sol-gel and self-combustion method has been employed to prepare $\mathrm{MgFe}_{2} \mathrm{O}_{4}$ spinel and $\mathrm{La}_{0.6} \mathrm{~Pb}_{0.2} \mathrm{Mg}_{0.2} \mathrm{MnO}_{3}$ perovskite for catalyst applications. It is an inexpensive method and the obtained prod- 


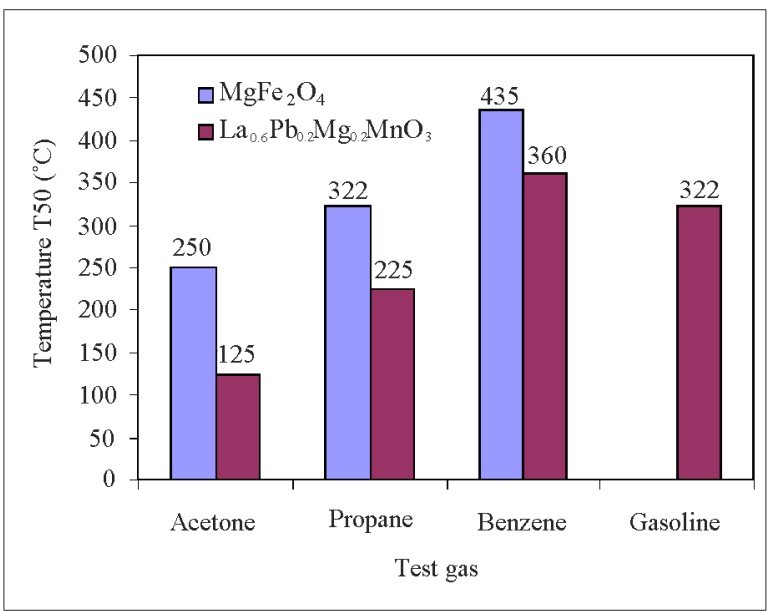

Figure 7. Bar diagram for the temperature of $50 \%$ conversion, $\mathrm{T}_{50}$, of acetone, propane and benzene on $\mathrm{MgFe}_{2} \mathrm{O}_{4}$ spinel and $\mathrm{La}_{0.6} \mathrm{~Pb}_{0.2} \mathrm{Mg}_{0.2} \mathrm{MnO}_{3}$ manganite catalysts.

ucts were pure and presented nanosized crystallinity. Both samples have been tested in the catalytic combustion of acetone, propane, benzene and $\mathrm{Pb}$ free gasoline. $\mathrm{La}_{0.6} \mathrm{~Pb}_{0.2} \mathrm{Mg}_{0.2} \mathrm{MnO}_{3}$ catalyst is more active at low temperatures compared to $\mathrm{MgFe}_{2} \mathrm{O}_{4}$ catalyst. Higher catalytic activity of the perovskite (over $90 \%$ gas conversion) is related to smaller crystallite size $(27 \mathrm{~nm})$, higher specific area $\left(8.5 \mathrm{~m}^{2} / \mathrm{g}\right)$ and the presence of manganese cations with variable valence $\left(\mathrm{Mn}^{3+}-\mathrm{Mn}^{4+}\right) . \mathrm{La}_{0.6} \mathrm{~Pb}_{0.2}$ $\mathrm{Mg}_{0.2} \mathrm{MnO}_{3}$ perovskite can be a promising catalyst for catalytic combustion of acetone and propane at low temperatures (bellow $300^{\circ} \mathrm{C}$ ).

\section{Acknowledgements}

This work was supported by a grant of the Romanian National Authority for Scientific Research, CNST-UEFISCDI, project number PN-II-ID-PCE-2011-3-0453.

\section{REFERENCES}

[1] A. C. F. M. Costa, R. T. Lula, R. H. G. A. Kiminami, L. F. V. Gama, A. A. de Jesus and H. M. C. Andrade, "Preparation of Nanostructured $\mathrm{NiFe}_{2} \mathrm{O}_{4}$ Catalysts by Combustion Reaction," Journal of Materials Science, Vol. 41, No. 15, 2006, pp. 4871-4875, doi:10.1007/s10853-006-0048-1

[2] M. F. M. Zwinkels, S. G. Jaras and P. G. Menon, "Catalytic Materials for High-Temperature Combustion," Catalysis Reviews: Science and Engineering, Vol. 35, No. 3, 1993, pp. 319-358. doi:10.1080/01614949308013910

[3] S. Ponce, M. A. Pena and J. L. G. Fierro, "Surface PropErties and Catalytic Performance in Methane Combustion of Sr-Substituted Lanthanum Manganites," Applied Catalysis B-Environmental, Vol. 24, No. 3-4, 2000, pp. 193205. doi:10.1016/S0926-3373(99)00111-3

[4] G. Saracco, F. Geobaldo and G. Baldi, "Methane Combustion on Mg-Doped $\mathrm{LaMnO}_{3}$ Perovskite Catalysts,"
Applied Catalysis B-Environmental, Vol. 20, No. 4, 1999 , pp. 277-288. doi:10.1016/S0926-3373(98)00118-0

[5] C. Oliva, L. Bonoldi, S. Cappelli, L. Fabbrini, I. Rossetti and L. Forni, "Effect of Preparation Parameters on $\mathrm{SrTiO}_{3 \pm \delta}$ Catalyst for the Flameless Combustion of Methane," Journal of Molecular Catalysis A-Chemical, Vol. 226, No. 1, 2005, pp. 33-40. doi:10.1016/j.molcata.2004.09.023

[6] P. D. Popa, N. Rezlescu and Gh. Iacob, "A New Procedure for Preparing Ferrite Powders," Romanian Patent No. 121300, 2008.

[7] S. Lowell, J. E. Shields, M. A. Thomas and M. Thommes, "Characterization of Porous Solids and Powders: Surface Area, Pore Size and Density," Kluwer Academic Publishers, Dordrecht/Boston/London, 2004. doi:10.1007/978-1-4020-2303-3

[8] R. Mahendiran, R. Mahesh, A. K. Raychaudhurim and C. N. R. Rao, "Room-Temperature Giant Magnetoresistance in $\mathrm{La}_{1-x} \mathrm{~Pb}_{x} \mathrm{MnO}_{3}$," Journal of Physics D-Applied Physics, Vol. 28, No. 8, 1995, pp. 1743-1745. doi:10.1088/0022-3727/28/8/027

[9] G. Leofanti, M. Padovan, G. Tozzola and B. Venturelli, "Surface Area and Pore Texture of Catalysts," Catalysis Today, Vol. 41, No. 1-3, 1998, pp. 207-219. doi:10.1016/S0920-5861(98)00050-9

[10] E. Kierlik, M. L. Rosinberg, G. Trajus and P. Viot, "Equilibrium and Out-Of-Equilibrium (Hysteretic) Behavior of Fluids in Disordered Porous Materials: Theoretical Predictions," Physical Chemistry Chemical Physics, Vol. 3, No. 7, 2001, pp. 1201-1206. doi:10.1039/b008636n

[11] N. Rezlescu, E. Rezlescu, P. D. Popa, E. Popovici, C. Doroftei and M. Ignat, "Preparation and Characterization of Spinel-Type $\mathrm{MeFe}_{2} \mathrm{O}_{4}(\mathrm{Me}=\mathrm{Cu}, \mathrm{Cd}, \mathrm{Ni}$ and $\mathrm{Zn})$ for Catalyst Applications," Material Chemistry and Physics, Vol. 137, No. 3, 2013, pp. 922-927. doi:10.1016/j.matchemphys.2012.11.005

[12] N. Rezlescu, E. Rezlescu, P. D. Popa, C. Doroftei and M. Ignat, "Nanostructured $\mathrm{GdAlO}_{3}$ Perovskite, a New Possible Catalyst for Combustion of Volatile Organic Compounds," Journal of Materials Science, Vol. 48, No. 12, 2013, pp. 4297-4304. doi:10.1007/s10853-013-7243-7

[13] R. Spinicci, M. Faticanti, P. Marini, S. De Rossi and P. Porta, "Catalytic Activity of $\mathrm{LaMnO}_{3}$ and $\mathrm{LaCoO}_{3}$ Perovskites towards VOCs Combustion," Journal of Molecular Catalysis A: Chemical, Vol. 197, No. 1-2, 2003, pp. 147-155, doi:10.1016/S1381-1169(02)00621-0

[14] J. Shu and S. Kaliaguine, "Well-Dispersed PerovskiteType Oxidation Catalysts," Applied Catalysis B: Environmental, Vol. 16, No. 4, 1998, pp. L303-L308. doi:10.1016/S0926-3373(97)00097-0

[15] A. A. Taskin, A. N. Lavrov and Y. Ando, "Fast Oxygen Diffusion in A-Site Ordered Perovskites," Progress in Solid State Chemistry, Vol. 35, No. 2-4, 2007, pp. 481490. doi:10.1016/j.progsolidstchem.2007.01.014

[16] H. Arai, T. Yamada, K. Eguchi and T. Seiyama, "Catalytic Combustion of Methane over Various PerovskiteType Oxides," Applied Catalysis, Vol. 26, No. 1-2, 1986, pp. 265-276. doi:10.1016/S0166-9834(00)82556-7 